\title{
Erythrocytosis in Spontaneously Hypertensive Rats
}

\author{
Subha Sen, George C. Hoffman, Nicholas T. Stowe, \\ Robert R. SMEby, and F. MERLiN Bumpus \\ From the Research Division and Department of Laboratory Hematology, \\ Cleveland Clinic Foundation, Cleveland, Ohio 44106
}

A в S T R ACT During the study of an inbred strain of Wistar rats which spontaneously develop hypertension when they reach a weight of approximately $150 \mathrm{~g}$, it was found that these animals also develop an erythrocytosis. A significant increase in red cell count was observed in spontaneously hypertensive $(\mathrm{SH})$ rats $(8-11 \times$ $10^{8} \mathrm{RBC} / \mathrm{mm}^{3}$ ) when compared with normotensive rats $\left(6-7 \times 10^{6} \mathrm{RBC} / \mathrm{mm}^{3}\right)$ of the same strain. This increase in red cell count paralleled the increase in body weight and the rise in blood pressure.

Since the plasma volume, as measured with labeled albumin was normal, there was an absolute increase in red cells. The hematocrit and hemoglobin content of the blood measured in $\mathrm{SH}$ rats were only slightly greater than those found in normotensive rats. However, the mean cell volume (MCV) of the red cells in the $\mathrm{SH}$ rats was $45-47 \mu^{3}$ as compared with $51-53 \mu^{3}$ in normotensive rats.

A fourfold increase in $24 \mathrm{hr}{ }^{59} \mathrm{Fe}$ incorporation into the red cells was found in the $\mathrm{SH}$ rats when compared with normotensive controls. The bone marrow of the $\mathrm{SH}$ rats showed erythroid hyperplasia. When the $\mathrm{SH}$ rats were treated with $\alpha$-methyldopa (Aldomet $200 \mathrm{mg} / \mathrm{kg}$ daily, i.p.) the red cell count fell in parallel with the drop in blood pressure. No change in red cell count or blood pressure was observed in normotensive rats treated in the same manner. The erythropoietin titer was high in $\mathrm{SH}$ rats, and was undetectable in normotensive rats. These observations suggest a direct relationship between the hypertension and the erythrocytosis mediated by erythropoietin; both are genetically controlled.

\section{INTRODUCTION}

Okamoto and Aoki (1) reported that they had bred a strain of Wistar rats which spontaneously develop hy-

Dr. Stowe is the recipient of a National Kidney Foundation Research Fellowship Grant.

Received for publication 11 November 1971 and in revised form 27 December 1971. pertension. The blood pressure in these rats remains constant and normal until they reach a weight of approximately $150 \mathrm{~g}$ from which time the blood pressure gradually rises in direct proportion to their weight. During the investigation of the cause of this hypertension, we found that the red cell count rises concommitantly and in direct proportion to the blood pressure. This paper reports our findings concerning the nature and cause of this erythrocytosis and its relationship to the hypertension.

\section{METHODS}

The spontaneously hypertensive Wistar rats $(\mathrm{SH})^{1}$ used in this study were either bred at the Cleveland Clinic Foundation or obtained from Purina Laboratory. ${ }^{2}$ Normal controls were either Sprague Dawley rats ${ }^{3}$ or rats from a normotensive Wistar strain. ${ }^{4}$ All rats were fed on commercial rat chow diet and tap water ad lib. Renal hypertensive rats were prepared by applying a silver clip to the left renal artery under ether anesthesia (2).

Blood pressure was measured at the same time of the day by the same person, using a tail cuff as described by Friedman and Freed (3). Blood was collected from the orbital cavity in conscious rats, from the tail artery under ether anesthesia or from the aorta when the animal was sacrificed, using sodium ethylenediaminetetraacetate (EDTA) as anticoagulant.

Blood counts and red cell indices were determined on a model S Coulter particle counter and platelets were counted on a model $\mathrm{F}$ Coulter particle counter. 5 Blood and bone marrow films were stained with Wright's stain, and reticulocytes were counted on blood films stained with brilliant cresyl blue.

Incorporation of radioactive iron into circulating red cells was reported as the percentage of a dose of $2 \mu \mathrm{Ci}{ }^{80} \mathrm{Fe}^{++}$ citrate in $0.1 \mathrm{ml}$ saline reappearing in the circulation $23 \mathrm{hr}$

\footnotetext{
${ }^{1}$ Abbreviations used in this paper: IRP, international reference preparation; $\mathrm{SH}$, spontaneously hypertensive.

${ }^{2}$ Purina Laboratory Animals, Vincentown, N. J.

${ }^{3}$ Carworth Division, Becton, Dickinson \& Co., New York.

${ }^{4}$ Hilltop Lab Animals, Inc., Scottdale, $\mathrm{Pa}$.

${ }^{5}$ Coulter Electronics, Inc., Hialeah, Fla.
} 
TABLE I

Hematological Characteristics of Normotensive, Spontaneously Hypertensive, and Renal Hypertensive Rats

\begin{tabular}{lcccccc}
\hline & $\begin{array}{c}\text { Normal } \\
\text { rats }\end{array}$ & \multicolumn{3}{c}{ Spontaneously hypertensive rats } & $\begin{array}{c}\text { Renal } \\
\text { hypertensive } \\
\text { rats }\end{array}$ \\
\hline Weight, $g$ & $200-300$ & $130-150$ & $180-200$ & $200-250$ & $250-300$ & $200-300$ \\
Blood pressure, $m m$ h & $110-120$ & $110-130$ & 180 & 200 & 200 & 210 \\
Number & 25 & 10 & 25 & 25 & 25 & 8 \\
RBC $\times 10^{6} / \mathrm{mm}^{3}$ & 6.8 & 6.4 & 8.1 & 8.7 & 10.0 & 6.8 \\
& $(0.1)$ & $(0.2)$ & $(0.1)$ & $(0.1)$ & $(0.1)$ & $(0.1)$ \\
WBC $\times 10^{3} / \mathrm{mm}^{3}$ & 9.2 & 8.4 & 9.3 & 8.4 & 10.6 & 10.5 \\
& $(0.3)$ & $(0.5)$ & $(0.3)$ & $(0.4)$ & $(0.5)$ & $(0.6)$ \\
Hemoglobin, $g / 100 m l$ & 14.7 & 13.5 & 14.8 & 15.7 & 16.6 & 13.3 \\
& $(0.2)$ & $(0.2)$ & $(0.1)$ & $(0.2)$ & $(0.1)$ & $(0.7)$ \\
Hematocrit, $\%$ & 37.6 & 36.5 & 37.6 & 40.8 & 44.1 & 39.8 \\
& $(0.6)$ & $(0.5)$ & $(0.1)$ & $(0.3)$ & $(0.4)$ & $(0.5)$ \\
MCV, $\mu^{3}$ & 54.2 & 55.5 & 47.0 & 45.8 & 45.4 & 53.5 \\
& $(0.6)$ & $(0.6)$ & $(0.2)$ & $(0.1)$ & $(0.1)$ & $(0.6)$ \\
\hline
\end{tabular}

Mean, with standard error of the mean in parenthesis.

after intravenous injection. The following formula was used:

Per cent incorporation ${ }^{59} \mathrm{Fe}=$

Radioactive counts $/ \mathrm{ml}$ whole blood at

$23 \mathrm{hr} \times$ blood volume $(\mathrm{ml})$

Total radioactive counts injected

Plasma volume was measured as the albumin- ${ }^{131} \mathrm{I}$ distribution space $20 \mathrm{~min}$ after the injection of $5 \mu \mathrm{Ci}$ tagged albumin. Autologous red cells collected in acid-citrate-dextrose and labeled with ${ }^{51} \mathrm{Cr}$ sodium chromate were used to measure red cell survival. The iliac artery was canulated under sodium amytal anesthesia (75 mg/kg i.p.); $1.5 \mathrm{ml}$ blood was withdrawn, labeled, and then reinjected through the cannula. $20 \mathrm{~min}$ later $0.3 \mathrm{ml}$ blood was collected and the cannula removed. This specimen was used to calculate the $100 \%$ level for red cell survival. Rats were bled at weekly intervals and radioactivity measured. Plasma iron was measured by atomic absorption.

Erythropoietin was measured by Dr. James Fisher (Department of Pharmacology, Tulane University), by injecting $1 \mathrm{ml}$ of serum $(0.5 \mathrm{ml}$ daily for 2 days $)$ into exhypoxic polycythemic mice. The results were expressed as per cent ${ }^{59} \mathrm{Fe}$ incorporation into $\mathrm{RBC}$ and converted into IRP (international Reference Preparation) units per milliliter from a $\log$ dose-response curve (4). $\alpha$-Methyldeoxyphenylalanine ( $\alpha$-methyldopa) was given in a single dose of $200 \mathrm{mg} / \mathrm{kg}$ i.p. daily.

\section{RESULTS}

The hematological characteristics of normotensive, spontaneously hypertensive, and renal hypertensive rats are

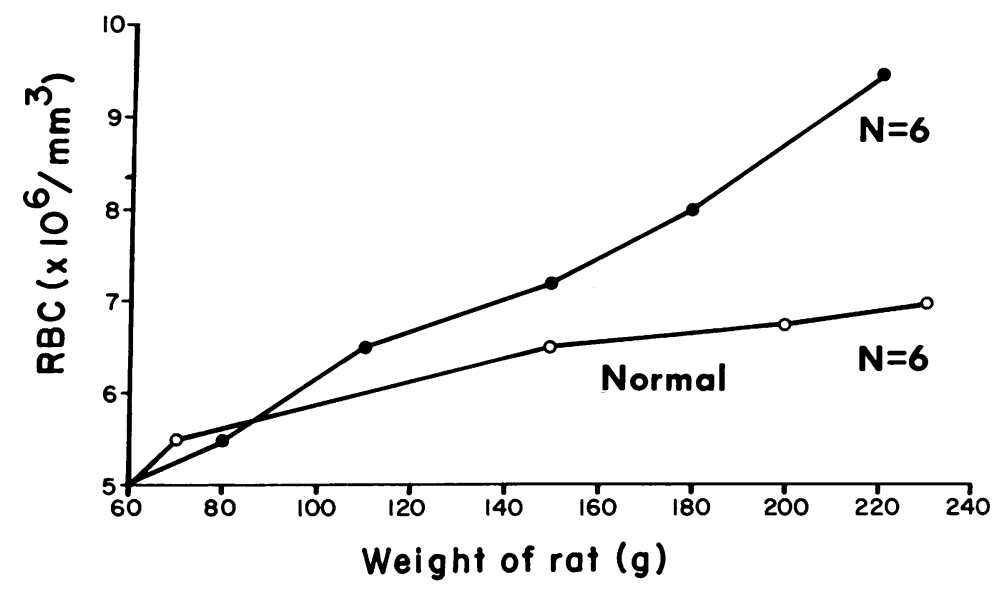

Figure 1 Red cell counts in six normal $(O)$ and $\operatorname{six} \mathrm{SH}(\bullet)$ rats studied for $8 \mathrm{wk}$ as their weight increased from 70 to $230 \mathrm{~g}$. 


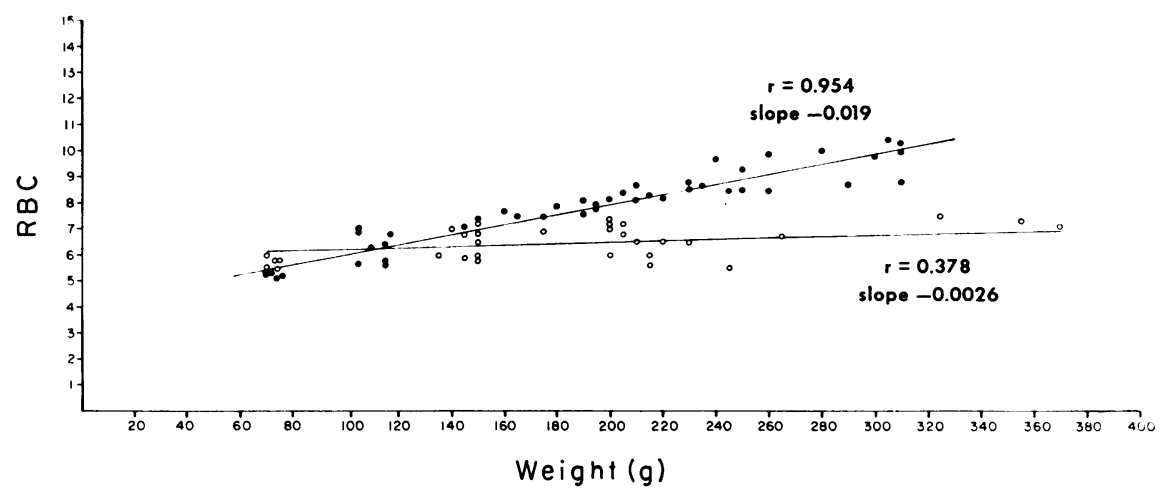

FIGURE 2 Red cell counts of $150 \mathrm{SH}$ rats and 75 normal rats plotted against their weight in grams. Regression lines indicate a direct relationship in $\mathrm{SH}$ rats $(r=$ $0.95, P<0.0001)$ and a lack of relationship $(r=0.38, P<0.4)$ in normal rats.

$\bullet, \mathrm{SH}$ rats; $\mathrm{O}$, normal rats.

presented in Table I. These characteristics were studied in rats of both sexes, but since no difference in red cell counts was observed mixed group data are reported. The results of the blood counts show that the red cell count in the $\mathrm{SH}$ rats increases as the weight and blood pressure increased. The red cells become smaller in size and this is reflected in a relatively smaller increase in blood hemoglobin content and hematocrit. The mean plasma volume of 15 normal rats was $39.08 \mathrm{ml} / \mathrm{kg}$ ( $\mathrm{SE}$ 0.46 ) and that of $15 \mathrm{SH}$ rats was $39.08 \mathrm{ml} / \mathrm{kg}$ (SE 0.88). A comparison between the body weight and red cell count shows a direct relationship based on a regression line calculated for the data shown in Fig. $2(r=0.95$, $P<0.0001$ ). The red cell count and body weight were measured at weekly intervals in six normal rats and six $\mathrm{SH}$ rats and the results (Fig. 1) were similar to those found in the larger groups (Fig. 2) which were not followed individually. The red cell counts also showed a linear relationship to the blood pressure $(r=0.95, P<$ 0.0001 Fig. 3 ). The mean quantity of radioactive iron $\left({ }^{50} \mathrm{Fe}\right)$ incorporated into red cells $23 \mathrm{hr}$ after injection was $8.8 \%$ in five normotensive rats with a mean red

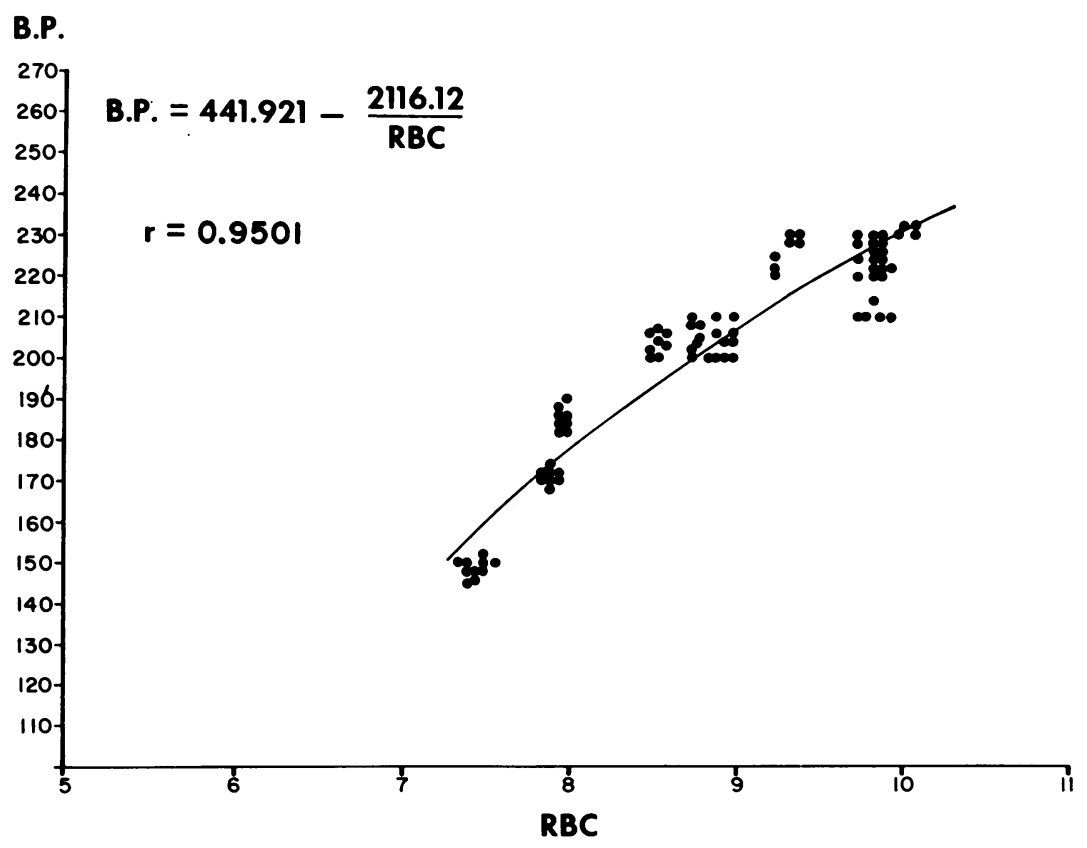

Figure 3 Blood pressure of $75 \mathrm{SH}$ rats plotted against their red cell counts. Regression line indicates a direct but not linear relationship $(r=0.95, P$ $<0.0001)$; the regression formula is shown. 
TABLE II

Effect of $\alpha$-Methyldopa (Aldomet) on Spontaneously Hypertensive and Normotensive Rats

\begin{tabular}{|c|c|c|c|c|c|c|}
\hline \multirow{4}{*}{$\begin{array}{l}\text { Blood pressure, } m m ~ H g \\
\text { RBC } \times 10^{6} / \mathrm{mm}^{3} \text { Erythrocyte } \\
\text { counts, }\left(\times 10^{6} / \mathrm{mm}^{3}\right)\end{array}$} & \multicolumn{3}{|c|}{ Normotensive } & \multicolumn{3}{|c|}{ Spontaneously hypertensive } \\
\hline & Before* & During $\ddagger$ & After $\S$ & Before* & During $\ddagger$ & After£ \\
\hline & $110 \pm 10$ & $100 \pm 10$ & $100 \pm 5$ & $200 \pm 10$ & \pm 15 & $200 \pm 10$ \\
\hline & $6.3 \pm 0.2$ & $6.5 \pm 0.3$ & $6.5 \pm 0.3$ & $\begin{array}{r}10.3 \pm 0.1 \\
9.5\end{array}$ & $\begin{array}{l}6.18 \pm 0.1 \\
79\end{array}$ & $8.9 \pm 0.2$ \\
\hline Plasma volume, $m l$ & $9.3 \pm 0.2$ & $8.5 \pm 0.4$ & & $9.5 \pm 0.5$ & $7.9 \pm 0.6$ & \\
\hline
\end{tabular}

Results expressed as mean \pm SEM of eight rats.

* Control data before drug treatment.

¥ Data obtained after 18 days of drug treatment.

$\S$ Data obtained 14 days after discontinuation of drug.

cell count of $6.5 \times 10^{6} / \mathrm{mm}^{3}$ and blood pressure of 100 $\mathrm{mm} \mathrm{Hg}$, and $41 \%$ ( $\mathrm{SE} \mathrm{2.16)}$ in five $\mathrm{SH}$ rats with a mean red cell count of $9.8 \times 10^{6} / \mathrm{mm}^{3}$ and blood pressure of $200 \mathrm{~mm} \mathrm{Hg}$. Red cell survival ( $\mathrm{t}_{\frac{1}{3}}$ ) was 9-16 days in five normal and nine to greater than 16 days in five $\mathrm{SH}$ rats. The reticulocyte count ranged from 140 to $210 \times$ $10^{3} / \mathrm{mm}^{3}$ in normal rats and ranged from 140 to $270 \times$ $10^{3} / \mathrm{mm}^{3}$ in $\mathrm{SH}$ rats. The bone marrow of three $\mathrm{SH}$ rats showed a marked erythroid hyperplasia when compared with the marrow of three normotensive rats. The marrow of one normotensive and one hypertensive rat were stained for iron; iron was present in both.

The plasma iron in two normal rats was 256 and $270 \mu \mathrm{g} / 100 \mathrm{ml}$ and in two hypertensive rats was 224 and $230 \mu \mathrm{g} / 100 \mathrm{ml}$.

Treatment with $\alpha$-methyldopa reduced the blood pressure and the red cell count in $\mathrm{SH}$ rats but affected neither parameter in normotensive rats (Table II). The reticulocyte count fell to a range of $7-7.5 \times 10^{3} / \mathrm{mm}^{3}$ in the $\mathrm{SH}$ rats. Discontinuation of the drug treatment led to a return of both hypertension and erythrocytosis in the $\mathrm{SH}$ rats. A typical response to a $\alpha$-methyldopa treatment is shown in Fig. 4. A similar effect was seen when guanethidine and hexamethonium were used to reduce the blood pressure. The greatest decrease in red cell count was seen in those $\mathrm{SH}$ rats that had the greatest fall in blood pressure. Serum erythropoietin titers are listed in Table III. The younger rats $(150-160 \mathrm{~g})$ have the highest titer $0.27 \mathrm{IRP} \mathrm{U} / \mathrm{ml}$. The titers in older rats were 0.15 and 0.17 IRP $\mathrm{U} / \mathrm{ml}$ in $180 \mathrm{~g}$ rats and 250 -g rats respectively. The erythropoietin titer was not detectable in normal rats.

\section{DISCUSSION}

The results of these studies show that the strain of Wistar rats which spontaneously develop hypertension also develop an erythrocytosis. Platelet and white cell production are not affected. Plasma volume measurements indicate that the erythrocytosis is absolute. The erythroid hyperplasia in the bone marrow and the four-

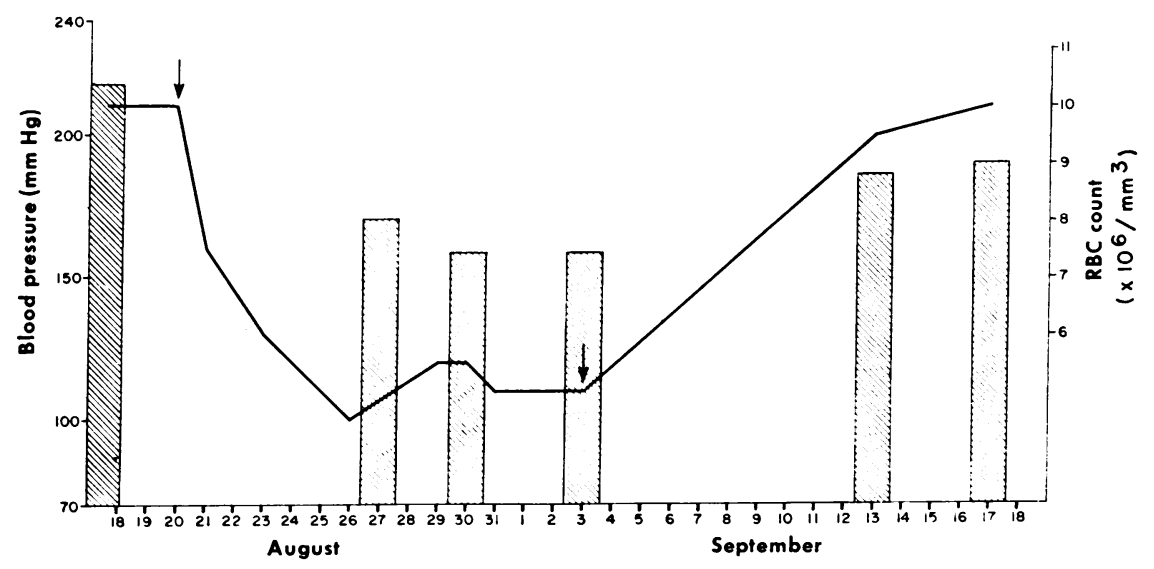

FigCRE 4 Typical changes of blood pressure and red cell count in a $\mathrm{SH}$ rat in response to $\alpha$-methyldopa treatment. Bars represent red cell count and line represents blood pressure. The first arrow indicates the beginning of treatment with Aldomet $(200 \mathrm{mg} / \mathrm{kg})$. The second arrow indicates the withdrawal of drug. 
TABLE III

Erythropoietin Titer in Serum of Spontaneously Hypertensive and Normotensive Rats

\begin{tabular}{|c|c|c|c|}
\hline Assay material & $\begin{array}{c}\text { No. of } \\
\text { assay mice }\end{array}$ & ${ }^{59} \mathrm{Fe}$ & $\begin{array}{l}\mathrm{ESF} \mathrm{U} / \mathrm{ml} \\
\quad(\mathrm{IRP})\end{array}$ \\
\hline & & $\%$ & \\
\hline Saline & 6 & 1.7 & none \\
\hline $\begin{array}{l}0.2 \mathrm{U} \\
\text { IRP }\end{array}$ & 5 & 8.11 & \\
\hline $\begin{array}{l}1.0 \mathrm{U} \\
\text { IRP }\end{array}$ & 5 & 27.14 & \\
\hline \multicolumn{4}{|l|}{ Pooled serum } \\
\hline $\begin{array}{l}\text { SH rats }(150-160 \mathrm{~g}) \\
\mathrm{n}=4\end{array}$ & 5 & 11.80 & 0.27 \\
\hline $\begin{array}{l}\text { SH rats }(180 \mathrm{~g}) \\
\mathrm{n}=3\end{array}$ & 5 & 4.08 & 0.15 \\
\hline $\begin{array}{l}\text { SH rats }(250-270 \mathrm{~g}) \\
\quad \mathrm{n}=3\end{array}$ & 5 & 6.14 & 0.17 \\
\hline $\begin{array}{l}\text { Normotensive rats } \\
n \mathrm{n}=4\end{array}$ & 5 & 0.75 & none \\
\hline
\end{tabular}

Results expressed as per cent ${ }^{59} \mathrm{Fe}$ incorporation and IRP* units per milliliter.

fold increase in iron turnover are further evidence of increased red cell production. The red cells that are produced during this phase have a significantly smaller MCV than the cells produced before the development of erythrocytosis. As a result, the blood hemoglobin content and hematocrit increase at a slower rate and this may in part account for the fact that the erythrocytosis has not been previously reported. The survival of these small red cells is normal. The reduction in size does not appear to be due to iron lack.

Erythropoietin is apparently the immediate stimulus to the increased red cell production. Plasma levels of the hormone are highest at the onset of the erythrocytosis but remain very high even when the red cell count is $10 \times 10^{6} / \mathrm{mm}^{3}$. The direct correlation between the blood pressure and the erythrocytosis suggests a causal relationship. Not only does the red cell count increase as the blood pressure rises, but also the red cell count decreases when the blood pressure is lowered by various antihypertensive drugs. Furthermore, when the drug treatment is discontinued, the blood pressure and the red cell count increase again. We have no evidence as to the source of erythropoietin in these $\mathrm{SH}$ rats. However, the kidney is a major source of erythropoietin (5). Fisher and Langston (6) suggest that renal hypoxia may be the stimulus to its production. Analysis of blood gases showed no change in oxygen tension in the arterial blood as the red cell count increased. One could postulate that hypertension reduces the renal blood flow or alters its intrarenal distribution in such a way that oxygen supply to the erythropoietin-producing cells is reduced.
Aoki (7) has shown that adrenalectomy reduces the blood pressure in the $\mathrm{SH}$ rats. We have studied four adrenalectomized $\mathrm{SH}$ rats and the red cell count decreased from a mean of $10-6.5 \times 10^{6} / \mathrm{mm}^{3}$ in 14 days and the blood pressure decreased from 200 to $150 \mathrm{~mm}$ $\mathrm{Hg}$. Although plasma volumes were not measured, these preliminary studies suggest that the adrenal gland may be involved in the production of hypertension and secondarily in the production of erythropoiesis. In this connection Waldmann and Bradley (8) reported the association of polycythemia and hypertension in a patient with pheochromocytoma and demonstrated the presence of an erythropoiesis-stimulating substance in chromaffin tumors.

Whatever the ultimate cause of the erythrocytosis and the hypertension is proven to be, the $\mathrm{SH}$ rats provide a readily available model for the study of spontaneous erythrocytosis due to increased erythropoietin production.

\section{ACKNOWLEDGMENTS}

We thank Dr. J. W. Fisher, Department of Pharmacology, Tulane University, for the erythroipoietin assay. We are grateful to Miss Betty Root, B. A., Miss Judy Rankin, M. T., ASCP, Mrs. Rita Block, B. S., and Miss Essie Foster for their expert technical assistance.

This work was supported by a NHLI grant HE-6835 and a grant from John A. Hartford Foundation.

\section{REFERENCES}

1. Okamoto, K., and K. Aoki. 1963. Development of a strain of spontaneously hypertensive rats. Jap. Circ. J. 27: 282.

2. Wilson, C., and F. B. Byron. 1941. Vicious circle in chronic Bright's disease. Experimental evidence from hypertensive rat. Quart. J. Med. 10: 65.

3. Friedman, M., and S. C. Freed. 1949. Microphonic manometer for indirect determinations of systolic blood pressure in the rat. Proc. Soc. Exp. Biol. Med. 70: 670.

4. Fisher, J. W., B. Roh, L. A. Malgar, J. Samuels, J. Thompson, R. Noveck, and J. Espoda. 1971. Chemical agents which stimulate erythropoietin production. In Kidney Hormones. J. W. Fisher, editor. Academic Press, Inc., New York. 345.

5. Jacobson, L. O., E. Goldwasser, W. Fried, and L. Plzak. 1957. Role of the kidney in erythropoiesis. Nature (London). 179: 633 .

6. Fisher, J. W., and J. W. Langston. 1968. Effects of testerone cobalt and hypoxia on erythropoietin production in the isolated perfused dog kidney. Ann. N. Y. Acad. Sci. 149: 75.

7. Aoki, K. 1963. Experimental studies on the relationship between endocrine organs and hypertension in spontaneously hypertensive rats. I. Effect of hypophysectomy, adrenalectomy, thyroidectomy, nephrectomy and sympathectomy on blood pressure. Jap. Heart J. 4: 443.

8. Waldmann, T. A., and J. E. Bradley. 1961. Polycythemia secondary to pheochromocytoma with production of an erythropoiesis stimulating factor by the tumor. Proc. Soc. Exp. Biol. Med. 108: 425. 